\title{
Identification of factors that interact with the E1A-inducible adenovirus E3 promoter
}

\author{
Helen C. Hurst and Nicholas C. Jones \\ Gene Regulation Group, Imperial Cancer Research Fund, London, England, WC2A 3PX
}

\begin{abstract}
We have investigated the E1A-inducible E3 promoter of adenovirus type 5 with respect to its ability to bind specific nuclear proteins. Four distinct nucleoprotein-binding sites were detected, located between positions -7 to $-33,-44$ to $-68,-81$ to -103 , and -154 to -183 , relative to the E3 cap site. These sites contain sequences previously shown to be functionally important for efficient E3 transcription. No major qualitative or quantitative differences were found in the binding pattern between nucleoprotein extracts prepared from uninfected or adenovirus-infected HeLa cells. Competition experiments suggest that the factors binding to the -154 to -183 and -81 to -103 sites are the previously identified nucleoproteins, NF1 and AP1, respectively. The factor binding to the -44 to -68 site, which we term ATF, also interacts with other E1A-inducible promoters and is very similar and probably identical to the factor that binds to the cAMP-responsive element of somatostatin. We have purified this factor, which is a protein of $43 \mathrm{kD}$ in size.
\end{abstract}

[Key Words: Trans-activation; gel retardation; footprinting; nuclear factors]

Received June 12, 1987; revised version accepted October 5, 1987.

The control of the rate of transcription initiation is an important element in the regulation of eukaryotic gene expression. Consequently, considerable effort is being devoted to elucidate the mechanisms by which transcription initiation can be modulated. For a variety of reasons, transcriptional regulation by the adenovirus immediate early ElA gene represents a very good model system for investigating such mechanisms. The E1A gene can transactivate a number of viral and cellular genes, and in many cases the promoters of such genes have been analyzed genetically to locate sequences or elements essential for efficient transcription (for review, see Berk 1986). The E1A gene can also repress expression of certain viral and cellular genes, specifically those dependent on cis-acting enhancer elements for efficient transcription (Borrelli et al. 1984; Hen et al. 1985; Velcich and Ziff 1985). Transcription stimulation by the SV40, Py, and E1A (Borrelli et al. 1984; Velcich and Ziff 1985) enhancers, as well as the cellular immunoglobulin heavy chain (Hen et al. 1985) and insulin (Stein and Ziff 1987) enhancers, has been shown to be blocked by E1A protein.

These two activities of E1A appear to be functionally distinct. At early times of infection, the E1A gene produces two transcripts, $12 \mathrm{~S}$ and $13 \mathrm{~S}$ in size, which encode products of 243 and 289 amino acids, respectively (Berk and Sharp 1978; Chow et al. 1979; Perricaudet et al. 1979; Kitchingman and Westphal 1980). Both products display regulatory activity; the product of 289 amino acids can trans-activate and repress gene transcription
(Borrelli et al. 1984; Velcich and Ziff 1985), whereas the protein of 243 amino acids, although it represses very efficiently (Borrelli et al. 1984; Velcich and Ziff 1985), is generally found to be deficient in trans-activation /Carlock and Jones 1981; Montell et al. 1982; Svensson and Akusjarvi 1984; Winberg and Shenk 1984; Lillie et al. 1986; Moran et al. 1986; Wu et al. 1986a). Furthermore, extensive mutational analysis of the E1A gene has identified domains that are required for repression but not for trans-activation (Lillie et al. 1986; Moran et al. 1986; Schneider et al. 1987). Consequently, these two regulatory activities of ElA have been shown to be separable, but their mode of action remains unclear. It is very unlikely that either trans-activation or repression is accomplished by sequence-specific binding of E1A protein to cis-acting regulatory elements because purified E1A proteins do not bind directly to DNA (Ferguson et al. 1985). In addition, there is only limited sequence homology between various promoters activated by ElA, and, except for the E1B promoter (Wu et al. 1987), mutational analysis has not led to the identification of sequences specifically required for ElA action; rather, it appears that it is the same promoter elements that are used both for basal level (uninduced) and E1A-induced transcription (for review, see Berk 1986). Thus, ElA must act in a more indirect fashion, possible by modulating the level or activity of nuclear transcription factors that interact with ElA inducible promoters.

Understanding how ElA trans-activates will therefore require a comprehensive understanding of the ElA-re- 
sponsive promoters in terms of the DNA sequences required for transcription and the factors that interact with these sequences. With this goal in mind, we have been studying the promoter of the adenovirus early gene E3, which is strongly stimulated by E1A, both in the virus and in DNA transfection experiments. Moreover, promoter mutagenesis and gene transfer experiments have identified elements required for efficient E3 transcription (Leff et al. 1985; Weeks and Jones 1985) and shown that upstream regions of this promoter can confer E1A inducibility on normally insensitive proximal promoter regions (Weeks and Jones 1985; Leff and Chambon 1986). In this report we describe four nuclear protein-binding sites, each of which corresponds to a region of the E3 promoter required for efficient transcription. These binding proteins are found in extracts prepared both from uninfected and adenovirus-infected cells. At least one of the factors appears to be very similar to a factor that also interacts with the E1A-inducible E2A and E4 promoters and to promoters that are activated by increasing cAMP levels. This factor has been purified to homogeneity and is a $43-\mathrm{kD}$ protein which we term ATF.

\section{Results}

Detection of factors that bind to the E3 promoter

Gene-transfer experiments have shown that E3 promoter sequences extending from the transcriptional start site to the EcoRI site, 237 bp upstream, are sufficient for full promoter activity and induction by ElA protein (Weeks and Jones 1985). Furthermore, a number of important cis-acting regulatory elements have been identified within this region (Leff et al. 1985; Weeks and Jones 1985), the removal or alteration of which results in lower uninduced and E1A-induced levels of transcription. The critical nature of these sequences suggests that they serve as binding sites for sequence-specific DNAbinding proteins. We have analyzed the proteins that interact with the $5^{\prime}$-control region of the E3 gene using the DNase I footprinting (Galas and Schmitz 1978) assay. In these studies we used specific DNA probes that encompass the cis-acting regulatory regions. The precise origin of these probes is described in Materials and methods, but briefly, probe A contains sequences from -37 to -237 and, therefore, has all the sequences necessary for promoter function, except that TATA-box region. Probes $\mathrm{B}$ and $\mathrm{C}$ do include this region and extend from positions +25 to -85 and from +65 to -77 , respectively.

${ }^{32}$ P-Labeled DNA and crude protein extracts from uninfected and Ad5-infected HeLa cell nuclei were incubated in the presence of nonspecific competitor DNA to allow the formation of specific DNA-protein complexes, as described in Materials and methods. These complexes were treated briefly with DNase I, and the resulting digestion patterns were resolved on DNA sequencing gels alongside digestion tracks obtained with naked DNA. The results are summarized in Figure 1. Four distinct protein-binding sites $(\mathrm{BS} 1-4)$ were de- tected as revealed by protection from digestion by the DNase I enzyme. The locations of the binding sites are as follows: (1) BS1 extends from -7 to -33 and includes the TATA-box region $(-29$ to -25$)$ in the area of protection, which is seen using probed $B$ and $C$ labeled on the coding and noncoding strands, respectively. The protection was not as strong as that seen in other areas of the promoter but was observed consistently using both uninfected and infected extracts. (2) Probe A labeled at position -37 on either the coding or noncoding strand revealed three clear footprints. BS2 is located between positions -44 and -68 , with the nucleotides at positions -68 and -69 , often showing hypersensitivity to digestion. (3) BS3 is farther upstream between nucleotides -81 and -103 , with the nucleotide at -104 being consistently hypersensitive to digestion. (4) BS4 is the most upstream site detected and extends from -154 to - 183. The exact location of this site was demonstrated more easily using probe A labeled at the EcoRI site at position -237 . The site is flanked on both strands by a number of nucleotides hypersensitive to digestion. Binding to this upstream site was especially easy to detect, which may reflect either a very strong DNA-protein interaction or a particularly abundant protein. The four sites all overlap with regions previously shown to be functionally important for transcription from the E3 cap site (see Discussion). The extent of the protected region and the degree of protection obtained was the same using several independent extracts prepared from both uninfected and adenovirus-infected cells and was not affected by the type of nonspecific competitor DNA [poly (dI/dC) or salmon sperm DNA] used.

The binding sites were analyzed further using the methylation protection assay. In these experiments, probe A was end-labeled with ${ }^{32} \mathrm{P}$ on either the coding or noncoding strand, incubated with extracts from uninfected cells, and subsequently treated with the reagent dimethylsulfate (DMS), which methylates guanine residues at position N7 (Maxam and Gilbert 1980). Those G residues in close proximity to the bound protein are protected from methylation. The DMS-treated DNA from incubations with (bound) and without (free) protein was treated with piperidine, which results in cleavage at methylated bases, and the cleaved DNA was resolved on denaturing acrylamide gels, as shown in Figure 2. Within BS2, G residues at positions $-53,-55$, and -58 on the coding strand and -57 on the noncoding strand were protected, as there was significantly less cleavage at these positions in the bound versus the free DNA. Similarly, G residues at -90 (coding) and -92 (noncoding/ were protected within binding site BS3, and residues at $-163,-164,-165,-168$, and -170 (coding) and $-166,-173,-174$ (noncoding) were protected within BS4. The protected residues are indicated by dots above the bases within the binding-site sequences shown in Figure 1. We did not detect any "methylation protection" sites outside the binding sites delineated previously by DNase I footprinting. We have provisionally named the four factors that interact with the E3 promoter E3.F1, E3.F2, E3.F3, and E3.F4. 


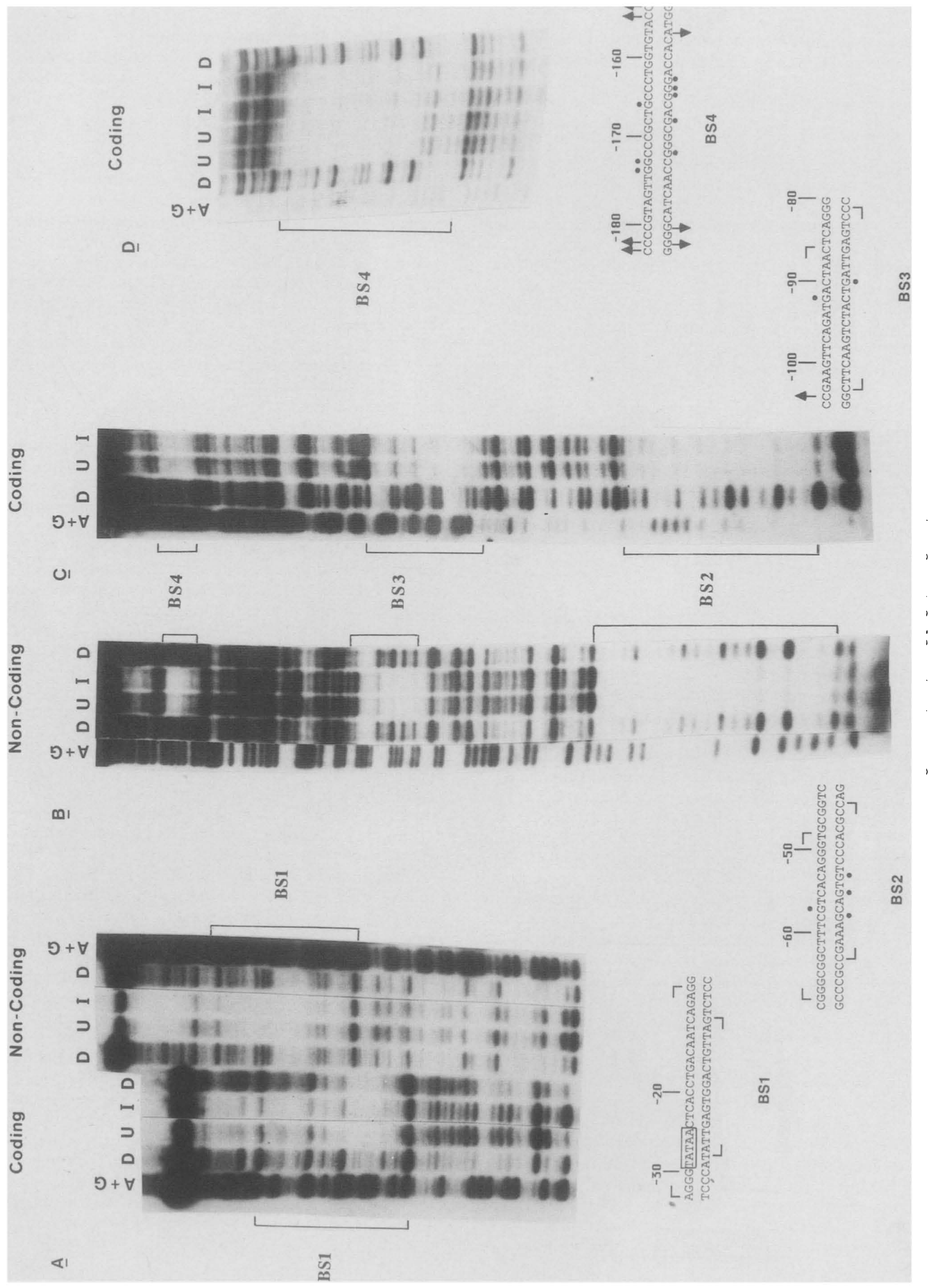




\section{Different proteins interact with each of the E3-binding sites}

Having identified four regions of the E3 promoter that interact with nuclear proteins, we prepared doublestranded DNA oligonucleotides of about $30 \mathrm{bp}$, containing individual sites BS2, BS3, and BS4 by chemical synthesis of the complementary single strands that were subsequently annealed (see Materials and methods). In addition, a double-stranded control oligonucleotide (nonsense oligonucleotide) that contained the E3 promoter sequence located between BS3 and BS4 was similarly prepared. By the DNase I footprinting assay, this region did not interact with any nuclear protein. Each of the oligonucleotides was ${ }^{32} \mathrm{P}$-end-labeled and analyzed for its ability to bind specific nuclear proteins, as revealed by the gel retention assay (Fried and Crothers 1981; Garner and Revzin 1981). In this assay, specific DNA-protein complexes are allowed to form in the presence of nonspecific competitor DNA, and the complexes are subsequently resolved from free DNA by nondenaturing gel electrophoresis. The BS2, BS3, and BS4 oligonucleotides all bound nuclear protein efficiently, as evidenced by the presence of retarded bands. The specificity of binding was demonstrated by competition experiments; binding to a labeled oligonucleotide was assayed in the presence of an excess of the identical unlabeled oligonucleotide, the nonsense oligonucleotide, or each of the oligonucleotides containing the other binding sites (Fig. 3). In all cases, binding to a labeled oligonucleotide was competed efficiently by an excess of itself but not at all by the nonsense oligonucleotide. Therefore, the binding detected is sequence specific. Oligonucleotides for BS2 and BS3 were also completely unable to compete for binding to BS4, and similarly BS4 did not compete for binding to BS2 and BS3. In contrast however, some competition was detected between BS2 and BS3. For example, unlabeled BS2 oligonucleotide could compete for binding to BS3, although less efficiently than the homologous BS3 oligonucleotide. The results indicate that some relationship between the binding-site specificities of factors E3.F2 and E3.F3 exists. However, the factors are almost certainly different because in both cases, cross-competition between the heterologous sites was not as efficient as competition with the homologous sites. Furthermore, the complexes formed with BS2 migrate slightly faster than the BS3 complex, again implying the involvement of two distinct factors.

\section{Relationship of the E3-binding factors to factors that bind to heterologous promoters}

We have examined the ability of other ElA-induced adenovirus early promoter sequences to compete for binding to the E3 promoter, or vice versa. Previous analysis of the E2A and E4 promoters indicated that similar factors might be interacting with specific regions of each promoter (Siva Raman et al. 1986; Lee and Green 1987). Moreover, these same investigators also observed some slight competition with the E3 promoter, which we investigated further. Initially, we prepared a probe from the E2A promoter ( -17 to -98$)$ that contains a binding site for a factor E2A.EF, identified by Siva Raman et al. (1986), and used this in gel-retention assays in the presence of E3 oligonucleotides. The DNA probe used contains a binding site for a second factor E2F, in addition to E2A.EF. However, in this in vitro assay, binding of the second factor is dependent upon the use of salmon sperm DNA as the nonspecific competitor. Under the conditions we use [i.e., poly $(\mathrm{d} / \mathrm{dC})$ as the competitor], only E2A.EF binding is detected (Siva Raman and Thimmappaya 1987; Yee et al. 1987). As shown in Figure 4A, the BS2 oligonucleotide showed strong competition for binding to the E2A promoter, whereas the BS3 oligonucleotide competed only weakly and the BS4 and nonsense oligomers did not compete at all. This suggests that E3.F2 and E2A.EF are the same factor. Lee and Green (1987) have described a factor, E4.F1, that binds to at least three regions of the $\mathrm{E} 4$ promoter and is also competed by E2 promoter sequences. Subsequent competition assays strongly suggest that E3.F2 and E4.F1 are also the same factor (Lee et al. 1987a). The possibility that all three factors are identical is based predominantly on the fact that all three bind an identical DNA sequence. Consequently, it cannot be ruled out that each represents a different member of a family of factors that have the same DNA-binding specificity. For the sake of discussion, however, we assume that the factors are identical and have renamed them ATF (Lee et al. 1987a).

By comparing the ATF-binding sites in the three adenovirus early promoters, a heptanucleotide consensus sequence T/G A/T CGTCA for ATF binding can be derived (Fig. 5A). A number of other viral and cellular promoters also contain this same consensus sequence, including genes such as the somatostatin gene, whose expression is activated by raising cAMP levels (Montminy et al. 1986). In the case of somatostatin, the con-

Figure 1. DNAse footprinting of the E3 promoter. (For details of probes, see Materials and methods.) Binding reactions with DNA alone (tracks $D$ ) or with extracts derived from uninfected $(\mathrm{U})$ or infected (I) cells were carried out as described in Materials and methods. The products of the DNase reactions were separated on sequencing gels, together with a Maxam and Gilbert A + G ladder for the particular probe. (A) Footprinting in the TATA-box region was examined using probes B (coding strand) and C (noncoding strand). In fact, BS1 and BS2 are present in these probes, but in this panel BS1 binding alone is indicated. (B) Footprinting using probe A filled in at the BamHI site (noncoding strand) covering the E3 promoter region between -37 and -237 . (C) Similar to B, but the probe was labeled on the coding strand. $(D)$ Footprinting in the -170 region using probe A labeled on the coding strand at the EcoRI site at -237 . The sequences of each of the sites BS1-BS4 are shown. Arrows indicate those bases consistently found to be hypersensitive to DNase digestion. Within BS2-BS4 are G residues whose methylation by DMS was protected by factor binding (see Fig. 2). These G residues are indicated by dots. 


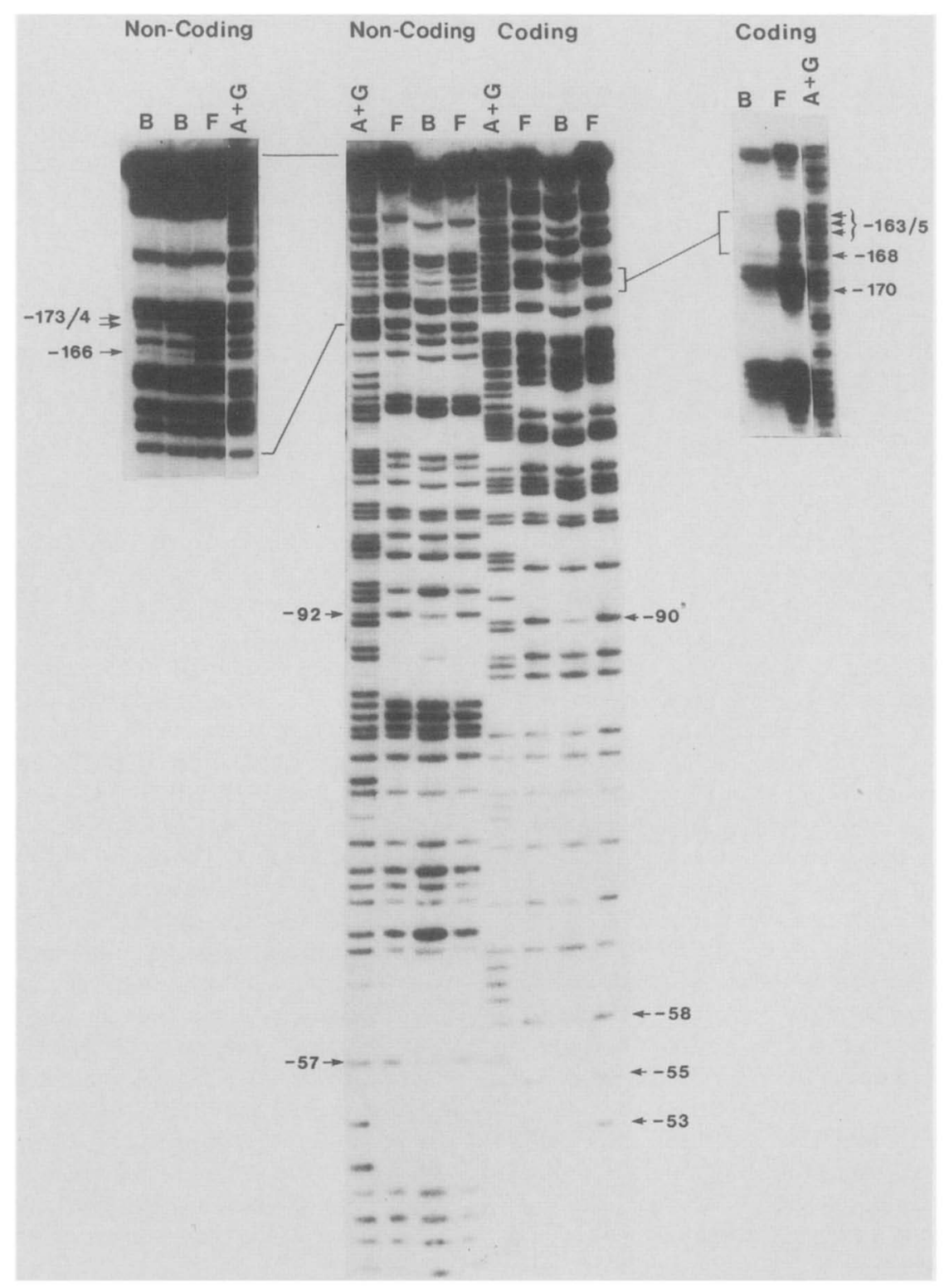

Figure 2. Methylation protection analysis. The main panel shows probe A, labeled either on the noncoding or coding strand proximal to position -37 , after methylation protection analysis (see Materials and methods) and electrophoresis on a $10 \%$ sequencing gel. Those G residues relatively protected from methylation in the bound (B) DNA, as compared with the free (F) DNA, are delineated by arrows. The upper regions of the gel have been expanded in the smaller panels. The noncoding panel shows the same probe run on a $6 \%$ sequencing gel, whereas the coding panel has probe A labeled at the EcoRI site at -237 . Again, protected bases observed consistently are marked with arrows.

sensus is within an area of the promoter critical for expression and recently shown to bind a specific phosphoprotein (Montminy and Bilezikjian 1987). We examined the relationship of this protein to ATF by performing a competition analysis similar to the one performed with the E2A promoter. An end-labeled probe derived from the rat somatostatin gene (extending from -10 to -70 ), which contains the ATF consensus sequence, was incubated with crude HeLa nuclear extract, and complex formation analyzed by the gel retention assay (Fig. 4B). A single retarded band was resolved that was competed away with the BS2 (ATF) oligomer very efficiently but not with the BS3, BS4, or nonsense oligomers. Therefore, the factor that binds to the somatostatin promoter is very closely related and probably identical to ATF.

The importance to binding of individual nucleotides within the ATF consensus sequence was examined by synthesizing a series of oligomers containing mutations within this sequence and assessing the ability of these mutant oligomers to compete for binding to the wildtype probe in gel-retention assays (Fig. 6). Oligomers containing mutations at positions $3,4,5$, or 7 within the heptanucleotide consensus all competed less efficiently, showing the critical importance of these sequences in 

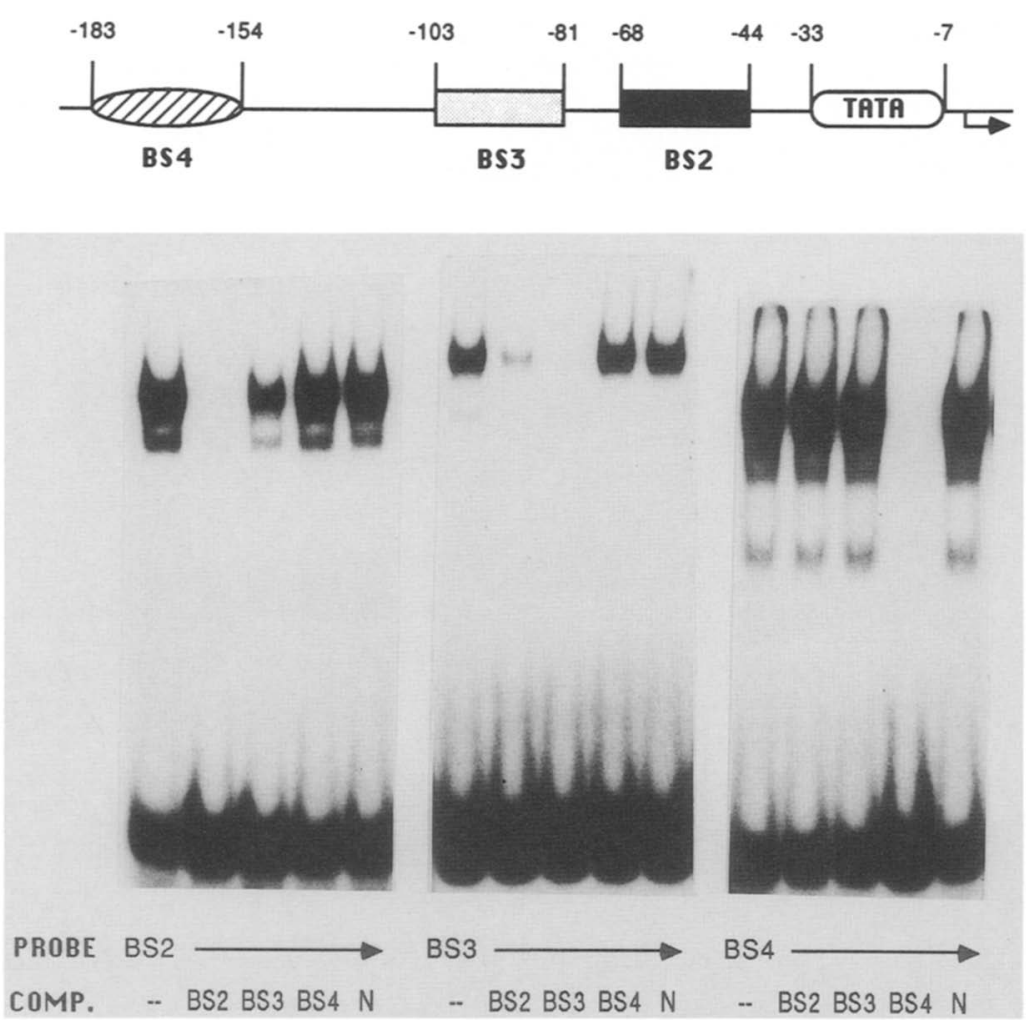

Figure 3. Competition analysis. (Top) A schematic diagram of the factor-binding sites within the E3 promoter. Each of the double-stranded DNA oligomers was labeled by filling in and was incubated $(0.1 \mathrm{ng})$ with $5 \mu \mathrm{g}$ of crude nuclear extract under standard conditions (see Materials and methods). For competition analysis, 500-fold molar excess of an unlabeled oligonucleotide was added to each incubation, as indicated. Samples were run on an $8 \%$ native gel. (BS2) Binding site 2 oligomer; (BS3) binding site 3 oligomer; (BS4) binding site 4 oligomer; $(N)$ nonsense oligomer. binding ATF. Surprisingly, mutations at positions 2 and 6 had less of an effect.

The ATF consensus is very similar to the consensus binding site (T G/T AGTCA G/C) for the nuclear factor AP1 (Angel et al. 1987; Lee et al. 1987b). This factor binds specifically to a number of regulatory regions, including the SV40 and Py enhancers, the human metallothionein IIA (MT IIA) and collagenase promoters, and the rat stromelysin promoter (Angel et al. 1987; Lee et al. 1987b). Comparison of the ATF- and AP1-binding sites reveals a clear difference at position 3 , which is a $C$ residue in the ATF site and an A residue in the AP1 site. One of the mutant BS2 oligomers that we synthesized contains this $\mathrm{C} \rightarrow \mathrm{A}$ transversion $(\mathrm{BS} 2 / 3)$; as a result, the mutant oligomer competed for ATF binding poorly, although some competition was still evident. This suggests that AP1 and ATF are different factors. The BS3 sequence, however, does contain the APl consensus (see Fig. $5 \mathrm{~B}$ ), and the competition results between $\mathrm{BS} 2$ and BS3 are similar to those obtained with the BS2/BS3 mutant and BS2 wild-type oligomers. This raised the possibility that the E3.F3 factor (which binds to BS3) is AP1. This possibility was explored further by additional competition analysis. A double-stranded DNA oligonucleotide containing the SV40 enhancer AP1-binding site (Lee et al. 1987b) was synthesized and tested for its ability to compete for binding to the E3 BS2 and BS3 sites. The results are shown in Figure 7, where the specific complexes are indicated by arrows. (We often detected a faster migrating complex, not competed in a specific fashion, which probably represents nonspecific binding to the oligomer ends.) The competing oligonucleotides were all present at a 100 -fold molar excess over the probe. Binding to the BS2 oligomer was competed efficiently by itself but only poorly by the BS3, BS2/3, or AP1 oligomers. In contrast, binding to the BS3 oligomer was competed efficiently by itself, by the BS2/3, and by the AP1 oligomers but not by the BS2 oligomer. Therefore, we conclude that the E3.F3 factor is very closely related and probably identical to the AP1 factor and that APl and ATF, although they have related binding sites, are distinct factors.

The E3 BS4 sequence contains homology to the binding site for the nuclear factor NF1, which has the

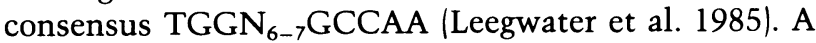
24-bp oligonucleotide containing the region of the Ad2inverted terminal repeat that is protected from DNase I digestion by the NF1 factor (Leegwater et al. 1985) was synthesized and tested for competition for binding to the BS4 oligonucleotide. The NF1 oligonucleotide competed very efficiently (data not shown); therefore, we conclude that the E3.F4 factor is NF1. Furthermore, affinity-purified NF1 (Jones et al. 1987) binds to the BS4 region very efficiently (T. Williams, unpubl.).

\section{The level of the E3-specific factors does not change following adenovirus infection}

All four factors that interact with the E3 promoter were clearly present in extracts from uninfected HeLa cells. Nevertheless, their concentration might be altered upon infection by adenovirus, and if one or more of the factors were limiting, an increase in their concentration could be a contributing factor to the activation of this pro- 


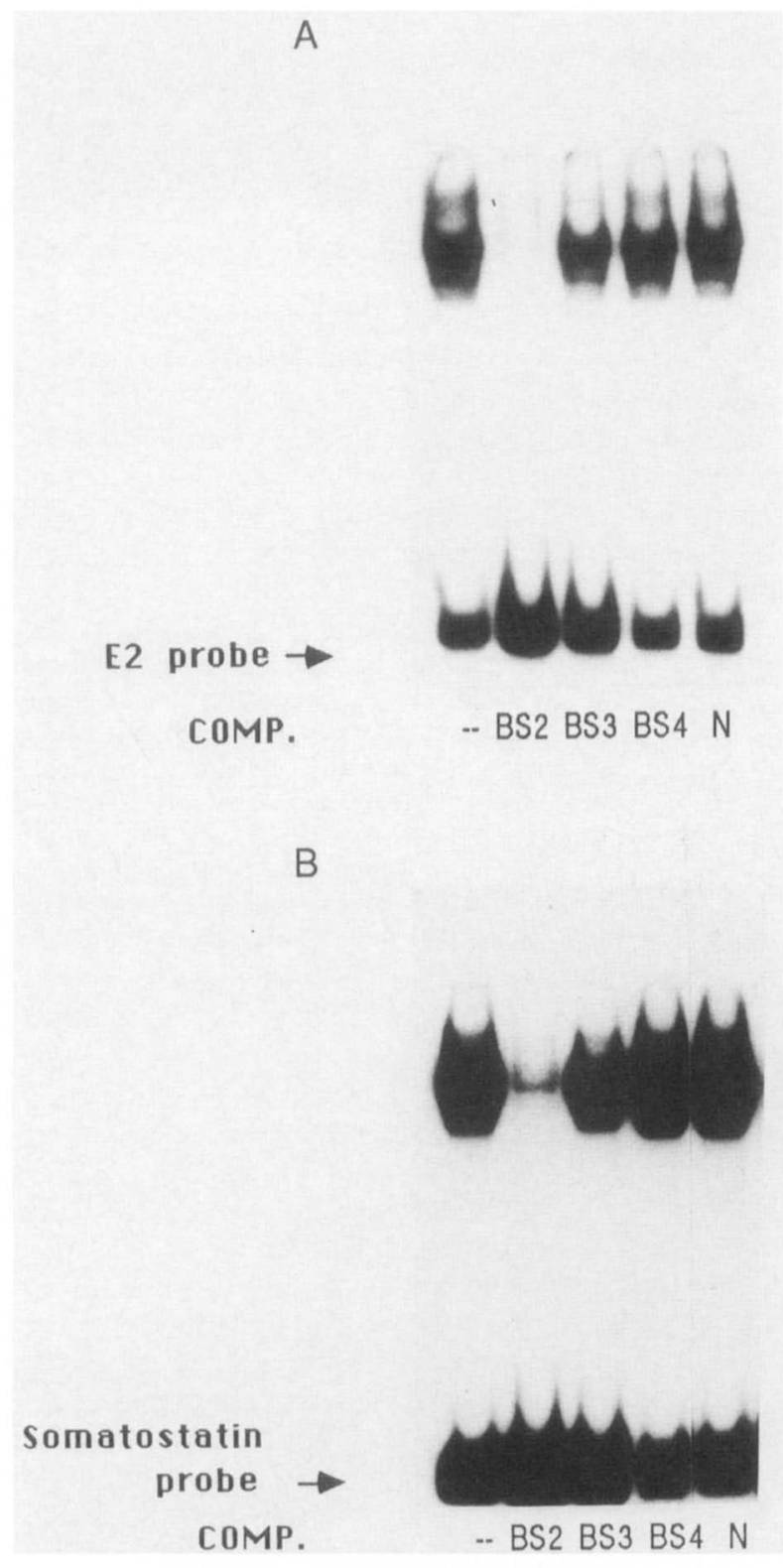

Figure 4. Comparison with other promoters. $(A)$ Approximately $1.0 \mathrm{ng}$ of the E2A probe (see Materials and methods) was incubated with $5 \mu \mathrm{g}$ of nuclear extract from uninfected cells and $1 \mu \mathrm{g}$ poly $(\mathrm{dI} / \mathrm{dC})$. For competition analysis, 135 -fold molar excess of unlabeled oligonucleotides was included as indicated, and the binding reactions were run on an $8 \%$ gel. $(B)$ Approximately $0.2 \mathrm{ng}$ of the somatostatin probe (see Materials and methods) were incubated with $5 \mu \mathrm{g}$ of nuclear extract and $1 \mu \mathrm{g}$ poly (dI/dC). For competition analysis, a 250 -fold molar excess of unlabeled oligonucleotides was added to the incubations as indicated. The samples were run on an $8 \%$ gel. (See legend to Fig. 3 for abbreviations.)

moter by E1A. However, this does not appear to be the case. Titration of uninfected and infected extracts, with respect to binding to each of the four E3-binding sequences, revealed no dramatic difference in the concentration of each factor between the two extracts (Fig. 8), although BS3 (AP1)-binding activity did appear to be approximately twofold lower in the infected extract. The infected extract was prepared from HeLa cells $6 \mathrm{hr}$ postinfection. If extracts were prepared at later times $(20 \mathrm{hr}$ postinfection), three- to fivefold lower levels of the factors binding to the BS2, BS3, and BS4 sites were seen (data not shown). This has been reported previously with respect to binding of ATF to the E2A promoter (Siva Raman et al. 1986) and is probably due to sequestration of factors by the very high copy number of adenovirus DNA template generated by viral DNA replication. Interestingly, binding to the BSl region was the same between uninfected and late-infected extracts. This may reflect either a higher abundance of this factor at late times of infection or more efficient dissociation from its template during the extraction procedure.

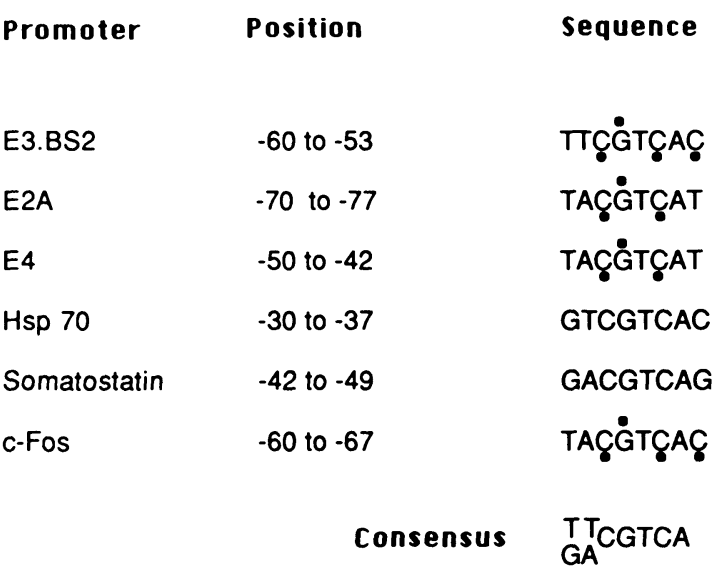

B

\begin{tabular}{|c|c|c|}
\hline E3.BS3 & -87 to -94 & TTAĞTÇAT \\
\hline SV 40 & 120 to 113 & TTAGTCAG \\
\hline Polyoma & 5120 to 5112 & TTAGTCAC \\
\hline Collagenase & -72 to -65 & TGAGTCAG \\
\hline Stromolysin & -71 to -66 & TGAGTCAG \\
\hline MT ॥A & -98 to -105 & TGAGTCAC \\
\hline & Consensus & $T_{G}^{\top} A G T C A$ \\
\hline
\end{tabular}

Figure 5. Comparison of factor-binding sites. $(A)$ The heptanucleotide core sequence within BS2 is shown compared to homologous sequences found within factor-binding sites characterized for other promoters: E4 (Lee and Green 1987); E2A (Siva Raman et al. 1986); Hsp 70 (Wu et al. 1986b); somatostatin (Montminy et al. 1986); c-fos (Gilman et al. 1986). Comparison of these sequences leads to a consensus ATF-binding site, as shown. $(B)$ Comparison of the core sequences within known AP1-binding sites and the E3 BS3 site. SV40 and metallothionein IIA (MT IIA) (Angel et al. 1987; Lee et al. 1987b); polyoma, collagenase, and stromolysin (Angel et al. 1987). Where binding factors have been mapped to these sequences using methylation protection analysis, the protected Gs are shown by dots. Gs protected on the opposite strand are indicated by a dot below the pairing $\mathrm{C}$ residue. 


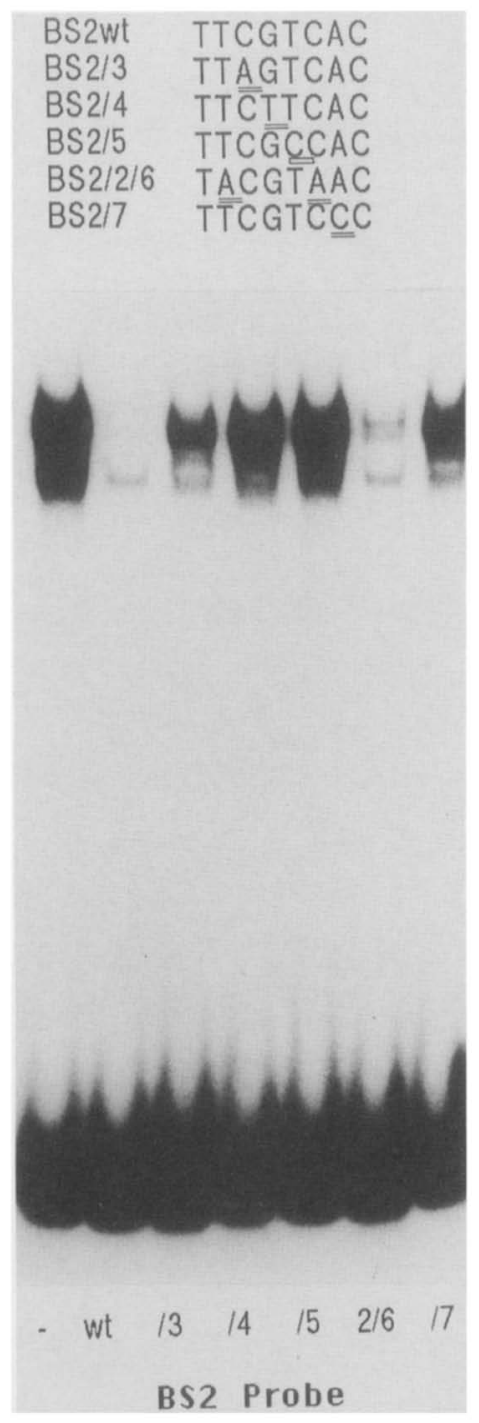

Figure 6. Mutation analysis of BS2. A series of oligomers based on BS2 were synthesized containing specific point mutations within the ATF consensus sequence; (top). End-labeled wild-type (wt) BS2 oligomer $(0.1 \mathrm{ng})$ was incubated with $5 \mu \mathrm{g}$ crude extract and $1 \mu \mathrm{g}$ poly $(\mathrm{dI} / \mathrm{pdC})$ with 150 -fold molar excess of the wild type and mutant BS2 oligomers, as indicated. Samples were run on $8 \%$ native gels.

\section{Purification of ATF}

Because ATF appears to bind to three early genes activated by E1A, it may play a crucial role in the activation process. Consequently, we have purified this factor to homogeneity using the purification scheme outlined in Figure 9A. The key step in the purification is the use of a specific DNA affinity resin (Kadonaga and Tiian 1986) containing the BS2-binding site. Prior to chromatography on the resin, the crude nuclear extract was chromatographed on the weakly acidic cationic exchange resin Biorex-70 and a calf thymus DNA-Sepharose column. Details of the purification are given in Materials and methods. Fractions containing ATF binding were determined by the gel-retention assay, using the
BS2 oligonucleotide as probe. Peak binding fractions were analyzed further by DNase I footprinting on probe A, which showed the gradual loss of BS3 (AP1)- and BS4 (NF1)-binding activities, whereas the BS2 (ATF) activity was retained and remained the only E3-binding activity in the affinity column eluant (data not shown). A portion of the peak fraction from the oligonucleotide affinity column was subjected to SDS gel electrophoresis, and separated proteins were revealed by silver staining. As shown in Figure 9B, the affinity column eluant contained a major band at $43 \mathrm{kD}$ and an additional series of bands between 60 and $65 \mathrm{kD}$. These latter bands were detected in all the tracks, including the control lane that contained sample buffer only. Therefore, we assume that these bands are nonspecific artifacts. The protein running as a $43-\mathrm{kD}$ species is therefore likely to be ATF. To determine unambiguously that indeed this species is the active binding protein, we subjected some of the affinity-purified protein to preparative SDS gel electrophoresis. Regions containing the $43-\mathrm{kD}$ and 60 to $65-\mathrm{kD}$ species were excised and eluted, and the resulting renatured proteins tested for the ability to bind to the BS2

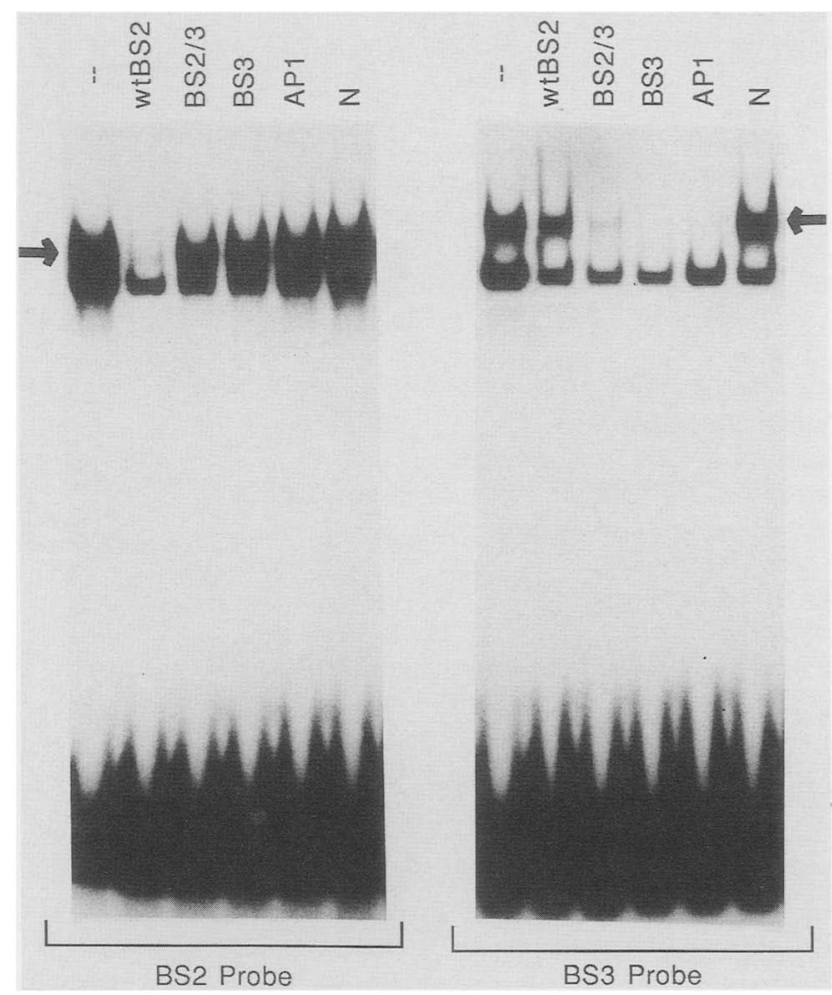

Figure 7. Competition between BS2 (ATF) and BS3 (AP1). Each of the incubations contained $0.1 \mathrm{ng}$ of end-labeled probe (either BS2 or BS3), $5 \mu \mathrm{g}$ of crude extract, $1 \mu \mathrm{g}$ poly $(\mathrm{dI} / \mathrm{pdC})$, and 100 fold molar excess of cold competitor oligomer, as indicated. Samples were run on $8 \%$ native gels. In each lane the retarded complexes consist of a ubiquitous, noncompetable complex and a competable, slower migrating complex, which is delineated by an arrow. (BS2) Binding site 2 oligomer; (BS3) binding site 3 oligomer; (BS2/3) binding site 2 oligomer with a mutation at position 3 in the ATF consensus (see Fig. 6); (AP1) 24-bp oligomer to the SV40 AP1-binding site (Lee et al. 1987b); (N) nonsense oligomer. 
Figure 8. Titration of uninfected and infected cell extracts. Each panel shows a gelretention assay with an oligomer probe representing one of the E3 factor-binding sites, titrated with nuclear extracts derived from uninfected (lanes 1-5) and Ad5 early infected (lanes $6-10)$ cells. $(A, C)$. Incubations in lanes $1,2,3,4$, and 5 and lanes $6,7,8,9$, and 10 contained $2,4,6,8$, and $10 \mu \mathrm{g}$ crude nuclear protein, respectively. $(B, D)$. Incubations in lanes $1,2,3,4$, and 5 and lanes 6,7 , 8,9 , and 10 contained $1,2,3,4$, and $5 \mu \mathrm{g}$ crude nuclear protein, respectively. All incubations included $0.1 \mathrm{ng}$ of the relevant end-labeled oligomer and poly $(\mathrm{dI} / \mathrm{dC})$ at a ratio of $1 \mu \mathrm{g} / 2.5 \mu \mathrm{g}$ of crude protein. Samples were run on $8 \%$ native gels.

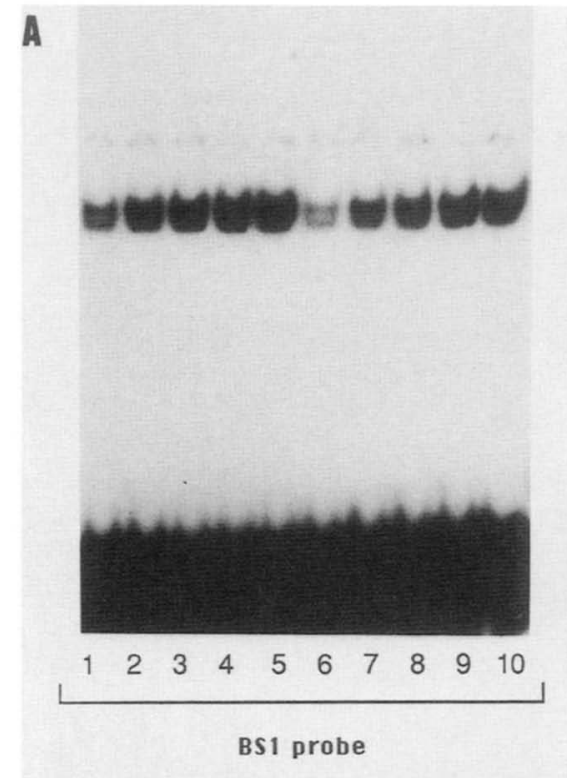

C
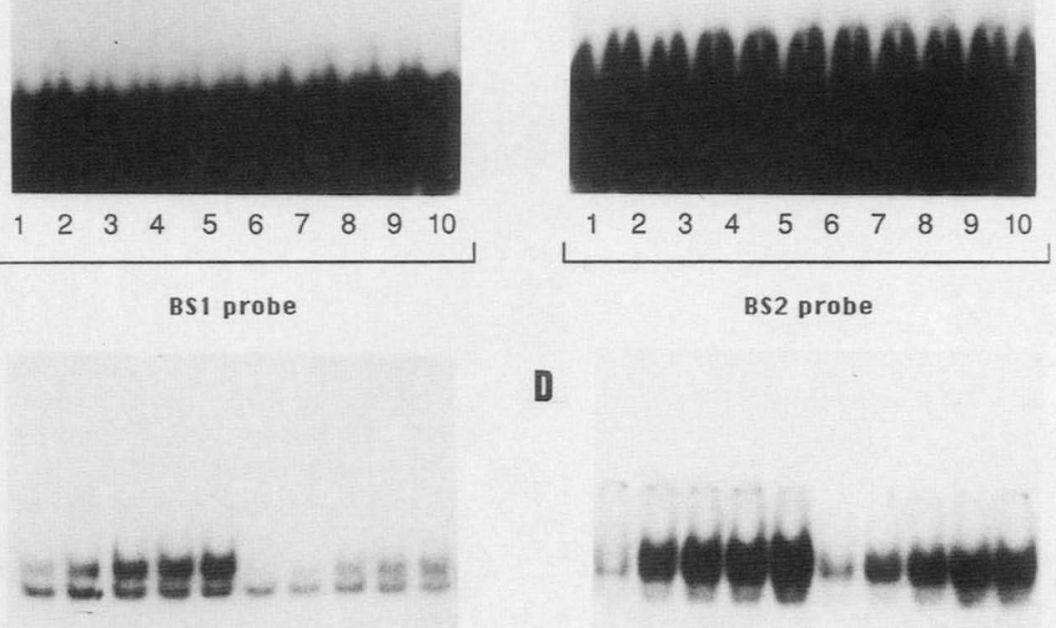

BS2 probe

D

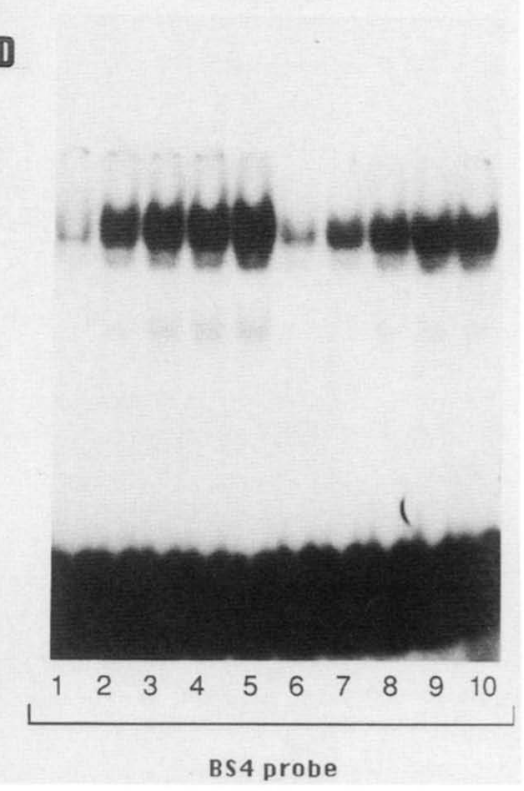

oligomer. As shown in Figure 9C, incubation with the $43-\mathrm{kD}$ protein resulted in retardation of the $\mathrm{BS} 2$ probe. We therefore conclude that the $43-\mathrm{kD}$ protein is the ATF factor.

\section{Discussion}

We have investigated the DNA sequences upstream of the E3 transcriptional start site for their capacity to interact specifically with nuclear proteins, using the DNase I footprinting technique. The results summarized in Figure 10 show that there are four distinct nuclear protein-binding sites. Each of these binding sites encompasses sequences that previously had been shown to be important for efficient transcription initiation from this promoter: (1) The most proximal binding site $(-7$ to -33$)$ contains the TATA-box sequences. A dele- tion of this region extending from nucleotide -15 to -35 was found to lower E3 transcription approximately fivefold (Leff et al. 1985). However, we have no direct evidence to suggest that the factor BS1, which we detect binding in this region, specifically recognizes the TATA box itself. (2) The next proximal binding site $(-44$ to -68 ) encompasses the nucleotides -55 to -57 found to be critical for promoter functions; a deletion from -39 to -55 was found to have relatively little effect on transcription, whereas a deletion from -39 to -57 reduced transcription significantly (Leff et al 1985). Consistent with these results, we found that a mutation at position 56 (BS2/BS5, Fig. 6) severely affected binding of ATF to this region of the promoter. Surprisingly, however, a mutation at position 54 (BS2/BS7) also diminished binding, although not quite as severely; this residue would be removed in the $-39 /-55$ deletion mutant. 
A

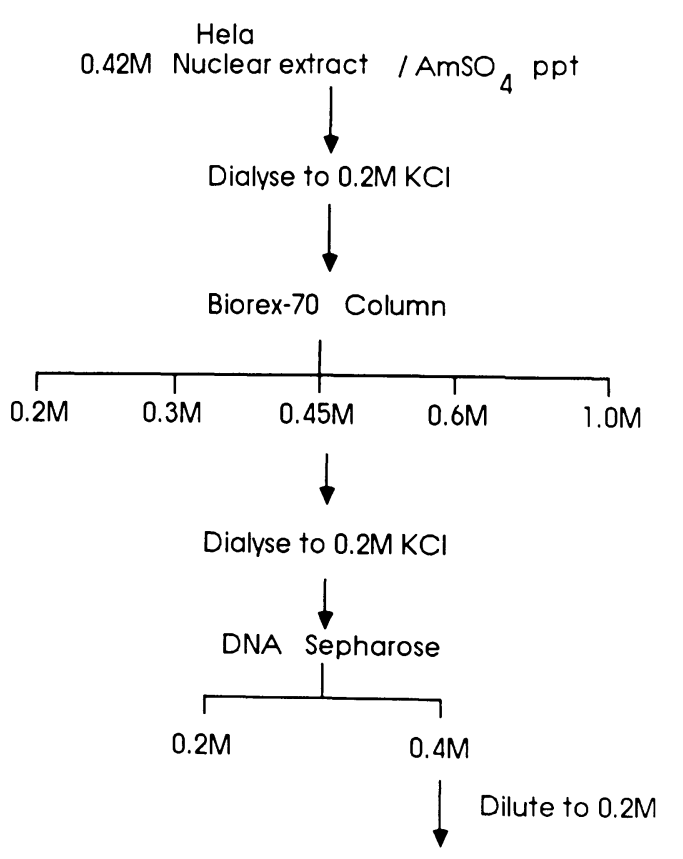

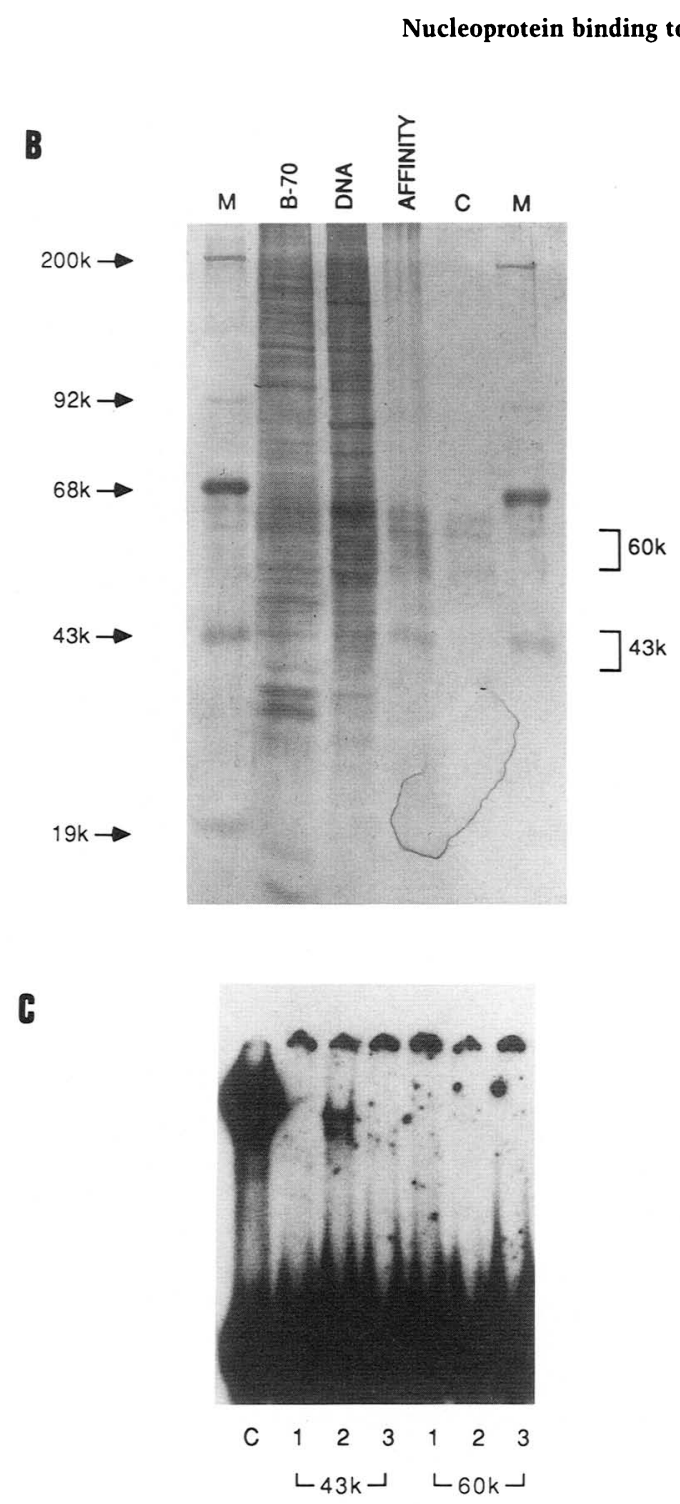

Oligonucleotide Affinity

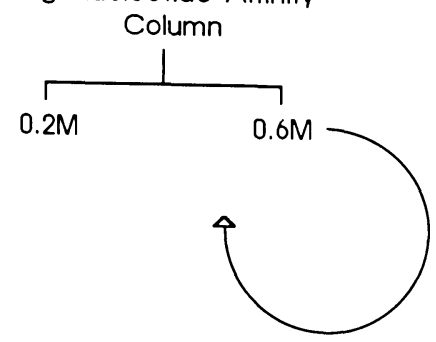

Dilute and reapply

Figure 9. Purification of ATF. (A) Scheme used for the purification of ATF. Precise details of the preparation and use of the columns are given in Materials and methods. (B) Silver-stained SDS-PAGE gel of samples from each stage of the purification. (B-70) Protein from the peak fractions of the Biorex-70 column; (DNA) peak fraction from the nonspecific DNA column; (affinity) protein after one pass over the BS2 oligomer affinity column; $(C)$ control lane containing sample buffer only. $(C)$ Gel retention analysis of $\sim 100$ ng of affinity-purified proteins eluted from the 43 and $60 \mathrm{~K}$ regions of a preparative gel after denaturation and renaturation (see Materials and methods). Incubations contained $0.1 \mathrm{ng}$ of end-labeled BS2. Lane C had $5 \mu \mathrm{g}$ crude extract and $1 \mu \mathrm{g}$ poly(dI/dC). For each protein sample, lanes 1-3 represent one-tenth the volume of successive fractions $(150 \mu \mathrm{l})$ collected from the renaturation gel filtration column. Samples were run on an $8 \%$ gel.

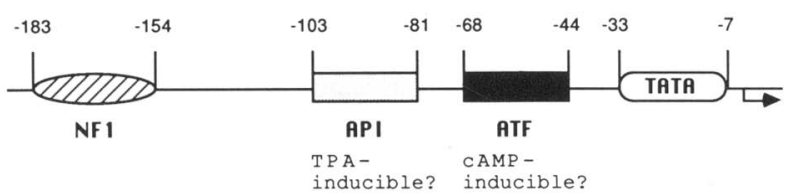

Figure 10. Summary of nuclear factors interacting with the E3 promoter. Shown is a schematic representation of the site of interaction of four nuclear factors that we have found to recognize the adenovirus E3 promoter. Two of the factors, namely AP1 and ATF, are implicated as mediators of inducers of gene transcription. The relevance of these inducers (TPA and cAMP) to $\mathrm{E} 3$ transcription and E1A transactivation remains to be established.
Additional experiments that fully explore the effect of point mutations on ATF binding and E3 transcription are in progress. (3) The binding site located between -81 and -102 coincides almost exactly with a functional promoter element defined by 5 '-deletion analysis of the promoter (Weeks and Jones 1985). Wild-type levels of transcription were obtained with upstream sequences extending to the EcoRI restriction site at position -237 . Deletions $5^{\prime}$ to position - 105 resulted in a small (twoto fourfold) reduction in transcription efficiency, but a further deletion to position -82 lowered transcription drastically, indicating the presence of a minor promoter element between -105 and -228 and a major promoter 
element between -82 and -105 . The major element thus coincides with BS3. (4) BS4 probably coincides with the minor promoter element upstream of position -105 , although the functionally important sequences in this region have not been defined precisely as yet. No proteins were found to interact with sequences that were neutral with respect to promoter function. Both qualitatively and quantitatively, the same nuclear proteinDNA interactions were observed regardless of whether the nuclear protein extracts were isolated from uninfected or adenovirus-infected HeLa cells. It is unlikely, therefore, that E1A stimulates E3 transcription by increasing the levels of limiting factors.

In all of these analyses it has been noted that deletion of the functional element did not abolish stimulation by the E1A protein, but rather the deletions lowered both uninduced and ElA-induced transcription, suggesting that the same elements and therefore presumably the same nuclear proteins are required for basal and induced E3 expression. However, the degree of stimulation by E1A was lower when either BS2 or BS3 was removed (Leff et al. 1985; Weeks and Jones 1985), possibly indicating that cooperation between the factors that interact with these two sites is necessary for full stimulation.

The factor that binds to the -44 to -68 region of E3, which we now call ATF, also binds to critically important regions of the $\mathrm{E} 2 \mathrm{~A}$ and $\mathrm{E} 4$ promoters (Lee et al. 1987a). It is possible therefore that this factor plays a crucial role in E1A trans-activation of these early genes. The human Hsp70 promoter is also induced by E1A /Wu et al. 1986a), and examination of the promoter sequence reveals a region just upstream of the TATA box that is identical to the ATF consensus sequence. Therefore, it is interesting to speculate that this site also binds the same factor, and indeed binding of a nuclear protein to this site has been detected (Greene et al. 1987). A number of other cellular and viral promoters contain the same consensus sequence (Fig. 5A). The c-fos promoter contains the consensus, and a protein that binds to this sequence has been detected (Gilman et al. 1986). Importantly the close contact points (as defined by methylation protection assays/ within the c-fos-binding site are identical to those found within the E3 BS2, making it very likely that the same protein is binding to each site. The site is also found in a functionally critical region of the somatostatin gene, which appears to be important for its inducibility by cAMP (Montminy et al. 1986). We show here that the BS2 oligomer competes efficiently for binding of a factor to this region of the somatostatin promoter, again indicating the very close relationship of this factor and ATF. This conclusion is substantiated further by our purification of ATF, revealing it to be a $43-\mathrm{kD}$ protein, identical in size to the phosphoprotein purified from the neuronal cell line PC12, which binds to the somatostatin sequence (Montminy and Bilezikjian 1987). A number of other genes inducible by cAMP contain the same consensus sequence. The interesting possibility that emerges, therefore, is that a common factor is at least partially mediating activation by cAMP and by E1A. Initial experiments indicate that raising
cAMP levels by treating HeLa cells with forskolin does not lead to activation of the E3 promoter (J. Jordan, $\mathrm{H}$. Hurst, and N. Jones, unpubl.). This might not be too unexpected, however, because it appears that although the consensus sequence is certainly a component of the cAMP response of the somatostatin gene, it is not in itself sufficient for cAMP inducibility (Montminy et al. 1986). It has been shown recently that increasing cAMP levels result in an increase in the phosphorylation of the $43-\mathrm{kD}$ factor that interacts with the somatostatin promoter (Montminy and Bilezikjian 1987). It would be of obvious interest to determine whether such an increase also occurs in response to the action of ElA.

The competition experiments strongly indicate that the factor that binds to the E3 BS3 is the previously identified factor AP1, and affinity-purified AP1 (Lee et al. 1987b) binds efficiently to this site (T. Williams, unpubl.). The AP1-binding site is found in a number of promoters that can be induced by phorbol esters such as 12-O-tetradecanoylphorbol-13-acetate (TPA), and a number of lines of evidence suggest that APl mediates this TPA response. For example, synthetic copies of the AP1-binding site can confer TPA inducibility upon heterologous promoters (Angel et al. 1987; Lee et al. 1987b). Our initial results indicate that the $\mathrm{E} 3$ promoter can be activated by TPA, although to a lesser degree than with ElA (J. Jordan, H. Hurst, and N. Jones, unpubl.); we have not shown that this TPA response requires that E3.F3 (AP1) factor, but this would seem likely to be the case. The mechanism by which AP1 mediates this response to TPA is not clear, but because TPA activates protein kinase $C$ it is tempting to speculate that as a result of TPA action, the phosphorylation state of the AP1 factor is increased. Likewise, it is possible that an increase in phosphorylation could also result from E1A action, a possibility that is currently being tested.

Both the ATF and AP1 factors appear to be highly conserved because we have found that factors with identical DNA-binding specificities are present in the fission yeast, Schizosaccaromyces pombe (R. Jones and $N$. Jones, unpubl.). Moreover, promoters such as E2A and E3, which normally require E1A transactivation to function efficiently, are active in $S$. pombe cells in the absence of E1A. It is interesting to speculate, therefore, that if ElA is mediating its response through specific activation of these factors, the factors are constitutively present in their "active". state in $S$. pombe. In contrast, the E3.F4 factor, which we have identified as being NF1, does not appear to be present in these yeast cells.

The mechanism by which ElA protein trans-activates is still unclear. It is very unlikely to act directly because isolated ElA protein lacks the ability to bind to DNA (Ferguson et al. 1985). It is more likely that it acts through the cellular transcription factors that interact with the inducible promoters. One possibility is that ElA induces a modification of these factors to increase their capacity for promoting transcription. Alternatively, E1A could result in an increase in the amount of a particular factor, and if that factor happened to be limiting, an increase in transcription would result. The 
early gene E2A promoter has been examined in some detail. In addition to ATF, a second factor, E2F, also interacts with critically important sequences of the E2A promoter (Kovesdi et al. 1986). This factor can be detected by in vitro-binding assays when salmon sperm DNA is used as the nonspecific DNA. When poly $(\mathrm{dI} / \mathrm{dC})$ is used instead, ATF binding and not E2F is predominantly detected (Siva Raman and Thimmappaya 1987; Yee et al. 1987). Interestingly, E2F DNA-binding activity is markedly increased upon infection with adenovirus, suggesting that activation of the E2A promoter by E1A is at least partially due to activation of the E2F factor (Kovesdi et al. 1986). It is not clear at present whether this activation is due to an increase in the actual level of E2F or a modification of a preexisting factor that markedly alters its DNA-binding properties. Recent evidence demonstrating the activation of E2A transcription in vitro by the addition of purified ElA protein suggests that the latter possibility is more likely (Spangler et al. 1987). The E2F factor appears to be unique among the factors that interact with the early promoters, because all the others, including those that bind to the E3 promoter, can be readily detected in extracts from uninfected cells. In these cases, it is possible that E1A-induced modification could affect some activity of the factor other than DNA binding. This may involve the physical relocation of factors within the nucleus, as has been suggested by Lee and Green (1987) who find that in vitro extracts from uninfected cells are as active in E4 transcription as infected whole cells. Alternatively, factor modification may alter interactions with other transcription factors and RNA polymerase II, so leading to the formation of stable initiation complexes. Obviously, a greater understanding of the functions of transcription factors, in general, and particularly those that interact with ElA-inducible promoters is required to elucidate fully this phenomenon. Such an understanding can only come from the purification and subsequent biochemical characterization of these factors.

\section{Materials and methods}

\section{Cells and extracts}

HeLa cells were grown in suspension in 2\% RPMI with $5 \%$ fetal calf serum and harvested at $5 \times 10^{5}$ to $8 \times 10^{5}$ cells $/ \mathrm{ml}$. Cells for infection were concentrated 10-fold and incubated with wild-type Ad5 at $20 \mathrm{pfu} / \mathrm{cell}$ for $1 \mathrm{hr}$ at $37^{\circ} \mathrm{C}$ before dilution back to $5 \times 10^{5}$ cells $/ \mathrm{ml}$ for a further $6 \mathrm{hr}$ (early infection) or $18 \mathrm{hr}$ (late infection) before harvesting.

Nuclear extracts were prepared from pelleted cells by the method of Dignam et al. (1983). The proteins were usually concentrated by addition of ammonium sulfate to $0.33 \mathrm{~g} / \mathrm{ml}$, with slow stirring for $30 \mathrm{~min}$ at $4^{\circ} \mathrm{C}$. The precipitate was collected by centrifugation at $25,000 \mathrm{~g}$ and resuspended at $10-25 \mathrm{mg} / \mathrm{ml}$ before dialysis versus three changes of dialysis buffer: $20 \mathrm{mM}$ HEPES- $\mathrm{KOH}$ ( $\mathrm{pH} 7.9$ ), $20 \%$ glycerol, $20 \mathrm{~mm} \mathrm{KCl}, 1 \mathrm{~mm} \mathrm{MgCl}$, $0.5 \mathrm{~mm}$ dithiothreitol (DTT), $0.5 \mathrm{~mm}$ PMSF. Extracts were stored in liquid nitrogen, and protein concentrations estimated using the BioRad assay kit versus plasma $\gamma$-globulin standards. Extracts prepared from adenovirus-infected cells were checked for the presence of E1A protein using Western blotting analysis (Feldman et al. 1982), with an ElA polyclonal rabbit antiserum raised against E1A expressed in Escherichia coli (Ferguson et al. 1984) and the Amersham horseradish peroxidase detection system.

Probes

E3 probes A, B, and C were derived from subclones of E3 promoter sequences. The 230-bp SmaI fragment between -37 and -268 was cloned into the SmaI site of pUC8. This clone was cleaved at the BamHI site (proximal to - 37) within the pUC8 polylinker and either incubated with $\left[a^{-32} \mathrm{P}\right] \mathrm{dATP}$ and reverse transcriptase to label the noncoding strand or treated with alkaline phosphatase followed by T4 kinase and [ $\gamma^{-32}$ P]ATP to label the coding strand. Subsequent cleavage with EcoRI released the 200-bp fragment designated probe A. Alternatively, the probe was labeled at the EcoRI site by filling in. Probes B and $\mathrm{C}$ were derived from an E3 promoter deletion mutant described by Weeks and Jones (1985), which was prepared by converting the DdeI $(-85)-$ Sau3A $(+65)$ restriction fragment into a BamHI fragment with linkers. Therefore, BamHI cleavage and incubation with reverse transcriptase and $\left[\alpha^{-32} \mathrm{P}\right] \mathrm{dATP}$ generated either probe B (labeled on the coding strand) after SacI $(+25)$ digestion or probe $C$ (labeled on the noncoding strand) after HhaI $(-77)$ digestion.

The E2A probe was obtained as described by Siva Raman et al. (1986) by labeling at the BssHII site (at -17 ) using reverse transcriptase and $\left[\alpha^{-32} \mathrm{P}\right] \mathrm{dCTP}$ and subsequent digestion with NarI (at -98). The rat somatostatin probe (Tavianini et al. 1984) was obtained by labeling at the BglII site (at - 70) using reverse transcriptase and $\left[\alpha-{ }^{32} \mathrm{P}\right] \mathrm{dATP}$ followed by SalI $(-10)$ digestion to release a 60 -bp probe.

All of the end-labeled probes were purified by acrylamide gel electrophoresis and electroelution. The isolated probes were ethanol-precipitated without the addition of carrier and recovered by ultracentrifugation at $100,000 \mathrm{~g}$.

$A+G$ marker tracks were prepared by treating labeled probes with $3 \%$ formic acid followed by piperidine cleavage (Maxam and Gilbert 1980).

\section{DNase footprinting and methylation protection assays}

The exact conditions for DNase footprinting were determined empirically for each probe and each extract examined. Binding reactions of $45 \mu \mathrm{l}$ in DNase buffer $[20 \mathrm{mM}$ HEPES-KOH $/ \mathrm{pH}$ 7.9), $50 \mathrm{~mm} \mathrm{KCl}, 20 \%$ glycerol, $2 \mathrm{mM}$ DTT, $2 \mathrm{~mm} \mathrm{MgCl}_{2}$ ] contained 150-200 $\mu \mathrm{g}$ of crude nuclear extract, $2-4 \mu \mathrm{g}$ nonspecific competitor, and $\sim 0.3 \mathrm{ng}$ end-labeled DNA probe. Incubations containing probe alone were also prepared. After $20 \mathrm{~min}$ at room temperature, 3-5 $\mu$ l of DNase I (Amersham), diluted to 5 $\mu \mathrm{g} / \mathrm{ml}$ in DNase buffer, was added for 30-60 sec. For "DNA only" incubations, DNase I was diluted to $0.1 \mu \mathrm{g} / \mathrm{ml}$. The reaction was stopped by addition of $50 \mu \mathrm{l}$ of proteinase $\mathrm{K}$ stop (buffer) [100 mM Tris-Cl (pH 7.5), 2\% SDS, 20 mM EDTA, 400 $\mu \mathrm{g} / \mathrm{ml}$ proteinase $\mathrm{K}$ ] for $10 \mathrm{~min}$ at $37^{\circ} \mathrm{C}$. Samples were extracted once with $100 \mu \mathrm{l}$ phenol mix (phenol, chloroform, isoamyl alcohol at $25: 24: 1)$ and precipitated with tRNA carrier. The dried pellets were Cherenkov counted, and equal counts loaded in all tracks on a standard $50 \%$ urea, $10 \%$ acrylamide sequencing gel, together with an appropriate $A+G$ marker lane.

For methylation protection assays, $45-\mu$ l binding incubations were set up using probe A as for DNase footprinting, and after $20 \mathrm{~min}$, each was treated with $2 \mu \mathrm{l}$ DMS (diluted fivefold in water) for 45-60 sec. The reaction was stopped by the addition 
of $1 \mu l \beta$-mercaptoethanol and $50 \mu l$ of proteinase $\mathrm{K}$ stop buffer, as above. Methylation of free probe was carried out according to Maxam and Gilbert (1980). The labeled DNA recovered from the protein bound and free probe samples was then cleaved by piperidine, and equal Cherenkov counts from bound and free samples run side by side on a standard $50 \%$ urea, $10 \%$ acrylamide sequencing gel.

\section{Gel retardation}

Binding reactions between nuclear extracts and end-labeled probes were carried out in 20- to $-25 \mu \mathrm{l}$ mixes in gel-retention buffer (GRB) : 25 mM HEPES-KOH (pH 7.9), 1 mM EDTA, 5 mM DTT, $10 \%$ glycerol, $150 \mathrm{~mm} \mathrm{NaCl}$. Typically, these incubations contained $\sim 0.1 \mathrm{ng}$ probe, $5-10 \mu \mathrm{g}$ crude protein extract, and 1-2 $\mu \mathrm{g}$ of nonspecific DNA competitor: either poly (dI/dC) (Pharmacia) or sonicated salmon sperm DNA (Sigma). Binding mixes were incubated for $20 \mathrm{~min}$ at $20^{\circ} \mathrm{C}$ and loaded directly onto $6-8 \%$ polyacrylamide gels (acryl : bis $=44: 0.8$ | and run in $0.5 \times \mathrm{TBE}$ for $90 \mathrm{~min}$ at $200 \mathrm{~V}$. Gels were then fixed and dried for autoradiography.

\section{Oligonucleotides}

We are grateful to Iain Goldsmith for preparing a series of oligonucleotides for us. The deprotected oligonucleotides were ethanol-precipitated, and the dried pellets resuspended in $98 \%$ formamide, $10 \mathrm{~mm}$ EDTA, and incubated for $2 \mathrm{~min}$ at $90^{\circ} \mathrm{C}$, and loaded onto a gel $1.5 \mathrm{~mm}$ thick, containing $50 \%$ urea, and $10 \%$ acrylamide. After electrophoresis at $60 \mathrm{~mA}$ in $1 \times \mathrm{TBE}$ the fulllength oligonucleotides were located by UV shadowing, excised from the gel, and eluted overnight (Maxam and Gilbert 1980). The purified oligomers were annealed as described (Kadonaga and Tjian 1986) to generate short double-stranded DNA regions containing a nucleoprotein-binding site.

Sequences contained within each double-stranded DNA oligomer, with respect to the E3 promoter, were as follows: BS1 oligomer $(-32$ to -7$)$; BS2 oligomer $(-44$ to -67$)$; BS3 oligomer $(-82$ to -103$)$; BS4 oligomer $(-157 \text { to }-180)_{\text {; }}$ nonsense oligomer ( -107 to -128$)$. All were constructed to give BamHI overhangs to the double-stranded DNA oligonucleotides. Incubations containing $\left[\alpha^{-32}\right.$ ] dATP and reverse transcriptase were used to label the oligomers for use as probes.

\section{Preparation of nonspecific and specific DNA affinity columns}

In each case, DNA was coupled to $\mathrm{CNBr}$-activated Sepharose 4B (Pharmacia), which had been hydrated and washed extensively in $1 \mathrm{mM} \mathrm{HCl}$. Coupling was carried out overnight at room temperature in $10 \mathrm{~mm} \mathrm{Na}$ phosphate buffer $(\mathrm{pH} 8.0)$ on a rotary shaker. After coupling, residual active groups in the resin were deactivated by incubation for $2-3 \mathrm{hr}$ at room temperature with $1 \mathrm{M}$ ethanolamine- $\mathrm{HCl}(\mathrm{pH} 9.0)$. Finally, the coupled resin was washed successively with $10 \mathrm{~mm} \mathrm{Na}$ phosphate $(\mathrm{pH}$ 8.0), $1 \mathrm{M} \mathrm{KCl}$, and oligonucleotide column storage buffer [Kadonaga and Tjian 1986: $10 \mathrm{~mm}$ Tris $(\mathrm{pH} 7.5), 0.3 \mathrm{M} \mathrm{NaCl}$, 1 mM EDTA, $0.02 \%$ azide].

DNA for the nonspecific column was derived as follows: Calf thymus double-stranded DNA (Sigma) was dissolved in water at $10 \mathrm{mg} / \mathrm{ml}$, sonicated briefly, and passed successively through 19 and 21-gauge needles. The DNA was then boiled for $10 \mathrm{~min}$ and quick-cooled on ice. Next, $20 \mathrm{mg}$ of this DNA was coupled per 5 grams of resin, and the efficiency was $70-80 \%$, giving a final concentration of $\sim 0.75 \mathrm{mg} \mathrm{DNA} / \mathrm{ml}$ of resin.

Oligonucleotide was prepared for the affinity column, largely as described by Kadonaga and Tiian (1986). End-labeled, ligated, double-stranded BS2 oligomer $(150 \mu \mathrm{g})$ was incubated with $6 \mathrm{ml}$ of resin. After coupling, the residual counts in the supernatant gave an estimated coupling efficiency of $80 \%$, that is, $20 \mu \mathrm{g}$ double-stranded oligomer/ml of gel.

\section{Purification of ATF}

Each stage of the purification was monitored by gel-retention assay of the fractions, using BS2 oligomer as probe to determine the peak of binding activity. Cleared crude extract $(10 \mathrm{ml}$ at 10 $\mathrm{mg} / \mathrm{ml}$ protein) was chromatographed over a $50-\mathrm{ml}$ Biorex-70 column (200-400 mesh, BioRad), equilibrated with $0.2 \mathrm{M} \mathrm{KCl}$ CB [column buffer: $20 \mathrm{~mm}$ HEPES (pH 7.9), 20\% glycerol, $1 \mathrm{~mm}$ EDTA, 0.1\% NP40, $0.5 \mathrm{~mm}$ DTT, $0.5 \mathrm{~mm}$ PMSF, $0.1 \mathrm{mg} / \mathrm{ml}$ leupeptin], and washed extensively with this buffer. The column was developed with successive step increases in $\mathrm{KCl}$ concentration to $0.3 \mathrm{M}, 0.45 \mathrm{M}, 0.6 \mathrm{M}$, and $0.75 \mathrm{M}$. BS2 activity eluted at $0.45 \mathrm{M} \mathrm{KCl}$, with an approximate fivefold increase in specific activity. The pooled fractions were dialyzed to $0.2 \mathrm{M}$ $\mathrm{KCl} \mathrm{CB}$ and applied to a 35-ml DNA-Sepharose column equilibrated with the same buffer. After extensive washing, ATF was eluted in one step with $0.4 \mathrm{M} \mathrm{KCl} \mathrm{CB}$, with a further increase in specific activity of three- to fourfold. These fractions were diluted to $0.2 \mathrm{M} \mathrm{KCl} \mathrm{CB}$ and applied to a $5-\mathrm{ml} \mathrm{BS2}$ oligomer affinity column equilibrated with the same buffer also containing $0.1 \mu \mathrm{M} \mathrm{ZnCl}_{2}$ (Lee et al. 1987b). The bound factor was washed and then eluted in one step with $0.6 \mathrm{M} \mathrm{CB}$. Flow of the column was interrupted for $10 \mathrm{~min}$ to allow dissociation before collection of the elution fractions.

Fractions from each step of the purification were run on standard $9 \%$ acrylamide-protein gels. Elution fractions were precipitated with $20 \%$ trichloroacetic acid (TCA) and resuspended in sample buffer $[31.25 \mathrm{~mm}$ Tris- $\mathrm{Cl}(\mathrm{pH} 6.8), 1 \%$ SDS, $5 \%$ glycerol, $2.5 \% \quad \beta$-mercaptoethanol, $0.0005 \%$ Pyronin Y]. Silver staining was performed as described by Sammons et al. (1981), and estimates of the concentration of ATF gave an approximate 1500 -fold increase in specific activity for the affinity column steps, that is, over 20,000 -fold purification over all.

Renaturation of ATF-binding activity from a preparative SDS gel was carried out as described by Lee et al. (1987b), except that the denaturation and renaturation buffer was $\mathrm{CB}$ with $0.15 \mathrm{M}$ $\mathrm{KCl}$. The net recovery of specific binding activity was $\sim 3 \%$.

\section{Acknowledgments}

We are indebted to Julie Jordan for preparing the nuclear extracts and to Richard Treisman for advice on the purification of ATF. We thank Mike Fried and Steve Goodbourne for critical reading of the paper and Julie Brister for preparing the manuscript.

\section{References}

Angel, P., M. Imagawa, R. Chiu, B. Stein, R.J. Imbra, H.J. Tahmsdorf, C. Jonat, P. Herrlich, and M. Karin. 1987. Phorbol ester-inducible genes contain a common cis element recognized by a TPA-modulated trans-acting factor. Cell 49: 729-739.

Berk, A.J. 1986. Adenovirus promoters and E1A activation. Annu. Rev. Genet. 20: 45-79.

Berk, A.J. and P.A. Sharp. 1978. Structure of adenovirus 2 early mRNAs. Cell 14: 695-711.

Borrelli, E., R. Hen, and P. Chambon. 1984. Adenovirus-2 E1A products repress enhancer-induced stimulation of transcription. Nature 312: 608-612. 
Carlock, L.T. and N.C. Jones. 1981. Transformation-defective mutant of adenovirus type 5 containing a single altered mRNA species. J. Virol. 40: 657-664.

Chow, L.T., T.R. Broker, and J.B. Lewis. 1979. The complex splicing patterns of RNA from the early regions of Ad2. $J$. Mol. Biol. 134: 265-303.

Dignam, J.D., R.M. Lebowitz, and R.G. Roeder. 1983. Accurate transcription initiation by RNA polymerase II in a soluble extract from isolated mammalian nuclei. Nucleic Acids Res. 11: $1475-1489$.

Feldman, L.T., M.J. Imperiale, and J.R. Nevins. 1982. Activation of early adenovirus transcription by the herpes virus immediate early gene: Evidence for a common cellular control factor. Proc. Natl. Acad. Sci. 79: 4952-4956.

Ferguson, B., N. Jones, J. Richter, and M. Rosenberg. 1984. Adenovirus E1A gene product expressed at high levels in $E$. coli is functional. Science 224: 1343-1346.

Ferguson, B., B. Krippl, O. Andrisani, N. Jones, H. Westphal, and M. Rosenberg. 1985. E1A 13S and 12S mRNA products made in $E$. coli both function as nucleus-localized transcription activators but do not directly bind DNA. Mol. Cell. Biol. 5: 2653-2661.

Fried, M. and D.M. Crothers. 1981. Equilibria and kinetics of lac repressor-operator interaction by polyacrylamide gel electrophoresis. Nucleic Acids Res. 9: 6505-6525.

Galas, D.J. and A. Schmitz. 1978. DNase footprinting: A simple method for the detection of protein-DNA binding specificity. Nucleic Acids Res. 5: 3157-3170.

Garner, M.M. and A. Revzin. 1981. A gel electrophoresis method for quantifying the binding of proteins to specific DNA regions. Nucleic Acids Res. 9: 3047-3060.

Gilman, M.Z., R.N. Wilson, and R.A. Weinberg. 1986. Multiple protein binding sites in the $5^{\prime}$-flanking region regulate $\mathrm{c}$-fos expression. Mol. Cell. Biol. 6: 4305-4316.

Greene, J.M., Z. Larin, I.C.A. Taylor, H. Prentice, K.A. Gwinn, and R.E. Kingston. 1987. Multiple basal elements of a human Hsp 70 promoter function differently in human and rodent cell lines. Mol. Cell. Biol. 7: 3646-3655.

Hen, R., E. Borrelli, and P. Chambon. 1985. Repression of the immunoglobulin heavy chain enhance by the adenovirus-2 E1A products. Science 230: $1391-1394$.

Jones, K.A., J.T. Kadonaga, P.J. Rosenfeld, T.J. Kelly, and R. Tjian. 1987. A cellular DNA-binding protein that activates eukaryotic transcription and DNA replication. Cell 48: 7989.

Kadonaga, J.T. and R. Tjian. 1986. Affinity purification of sequence-specific DNA binding proteins. Proc. Natl. Acad. Sci. 83: 5889-5893.

Kitchingham, G.R. and H. Westphal. 1980. The structure of adenovirus 2 early nuclear and cytoplasmic RNAs. I. Mol. Biol. 137: 23-48.

Kovesdi, I., R. Reichel, and J.R. Nevins. 1986. Identification of a cellular transcription factor involved in ElA transactivation. Cell 45: 219-228.

Lee, K.A.W. and M.R. Green. 1987. A cellular transcription factor E4F1 interacts with an E1A-inducible enhancer and mediates constitutive enhancer function in vitro. EMBO I 6: $1345-1353$.

Lee, K.A.W., T.-Y. Hai, L. Siva Raman, B. Thimmappaya, H.C. Hurst, N.C. Jones, and M.R. Green. 1987a. A cellular transcription factor ATF activates transcription of multiple ElA-inducible adenovirus early viral promoters. Proc. Natl. Acad. Sci. (in press).

Lee, W., P. Mitchell, and R. Tjian. 1987b. Purified transcription factor AP-1 interacts with TPA-inducible enhancer elements. Cell 40: 741-752.
Leegwater, P.A.J., W. van Driel, and P.C. van der Vliet. 1985. Recognition site of nuclear factor 1, a sequence-specific DNA binding protein from HeLa cells that stimulates adenovirus DNA replication. EMBO I. 4: 1515-1521.

Leff, T. and P. Chambon. 1986. Sequence-specific activation of transcription by adenovirus ElA products is observed in HeLa cells but not in 293 cells. Mol. Cell. Biol. 6: 201-208.

Leff, T., J. Corden, R. Elkaim, and P. Sassone-Corsi. 1985. Transcriptional analysis of the adenovirus-5 E3 promoter: Absence of sequence specificity for stimulation by ElA gene products. Nucleic Acids Res. 13: 1209-1221.

Lillie, J.W., M. Green, and M.R. Green. 1986. An adenovirus ElA protein region required for transformation and transcriptional repression. Cell 46: 1043-1051.

Maxam, A.M. and W. Gilbert. 1980. Sequencing end-labeled DNA with base specific chemical cleavages. Methods Enzymol. 65: 499-560.

Montell, C., C. Courtois, C. Eng, and A.J. Berk. 1982. Complete transformation by adenovirus 2 requires both E1A proteins. Nature 295: 913-919.

Montminy, M.R. and L.M. Bilezikjian. 1987. Binding of a nuclear protein to the CAMP responsive element of the somatostatin gene. Nature 328: 175-178.

Montminy, M.R., K.A. Sevarino, J.A. Wagner, G. Mandel, and R.H. Goodman. 1986. Identification of a cAMP-responsive element within the rat somatostatin gene. Proc. Natl. Acad. Sci. 83: 6682-6686.

Moran, E., T. Grodzicker, R.J. Roberts, M. Mathews, and B. Zerler. 1986. Lytic and transforming functions of individual products of the adenovirus ElA gene. J. Virol. 57: 765-775.

Perricaudet, M., G. Akusjarvi, and A. Virtanen. 1979. Structure of two spliced mRNAs from the transforming region of human subgroup C adenovirus. Nature 281: 694-696.

Sammons, D.W., L.D. Adams, and E.E. Nishizawa. 1981. Ultrasensitive silver based color staining of polypeptides in polyacrylamide gels. Electrophoresis 2: 135-141.

Schneider, J.F., F. Fisher, C.R. Goding, and N.C. Jones. 1987. Mutational analysis of the adenovirus E1A protein: The role of transcriptional regulation in transformation. EMBO $\mathrm{J}$. 6: 2053-2060.

Siva Raman, L., S. Subramanian, and B. Thimmappaya. 1986. Identification of a factor in HeLa cells specific for an upstream transcriptional control sequence of an E1A-inducible adenovirus promoter and its relative abundance in infected and uninfected cells. Proc. Natl. Acad. Sci. 83: 5914-5918.

Siva Raman, L. and B. Thimmappaya. 1987. Two promoter-specific host factors interact with adjacent sequences in an ElA-inducible adenovirus promoter. Proc. Natl. Acad. Sci. 84: 6112-6116.

Spangler, R., M. Bruner, B. Dalie, and M.L. Harter 1987. Activation of adenovirus promoters by the adenovirus ElA protein in cell-free extracts. Science 237: 1044-1046.

Stein, R.W. and E.B. Ziff. 1987. Repression of insulin gene expression by adenovirus type 5 ElA proteins. Mol. Cell. Biol. 7: 1164-1170.

Svensson, C. and G. Akusjarvi. 1984. Adenovirus 2 early region $1 \mathrm{~A}$ stimulates expression of both viral and cellular genes. EMBO I. 3: 789-794.

Tavianini, M.A., T.E. Hayes, M.D. Magazin, C.D. Minth, and J.E. Dixon. 1984. Isolation, characterization, and DNA sequence of the rat somatostatin gene. J. Biol. Chem. 259: 11798-11803.

Velcich, A. and E. Ziff. 1985. Adenovirus E1A proteins repress transcription from the SV40 early promoter. Cell 40: 705716.

Weeks, D.L. and N.C. Jones. 1985. Adenovirus E3-early pro- 
moter: Sequences required for activation by ElA. Nucleic Acids Res. 13: 5389-5401.

Winberg, G. and T. Shenk. 1984. Dissection of overlapping functions within the adenovirus type $5 \mathrm{E} 1 \mathrm{~A}$ gene. $E M B O J$. 3: 1907-1912.

Wu, B.J., H.C. Hurst, N.C. Jones, and R.I. Morimoto. 1986a. The E1A 13 product of adenovirus 5 activates transcription of the cellular human HSP70 gene. Mol. Cell. Biol. 6: 29942999.

Wu, B.J., R.E. Kingston, and R.I. Morimoto. 1986b. Human HSP70 promoter contains at least two distinct regulatory domains. Proc. Natl. Acad. Sci. 83: 629-633.

Wu, L., D.S.E. Rosser, M.C. Schmidt, and A. Berk. 1987. A TATA box implicated in E1A transcriptional activation of a simple adenovirus 2 promoter. Nature 326: 512-515.

Yee, A.S., R. Reichel, I. Kovesdi, and J.R. Nevins. 1987. Promoter interaction of the E1A-inducible factor and its potential role in the formation of a multi-component complex. $E M B O$ J. 6: 2061-2068. 


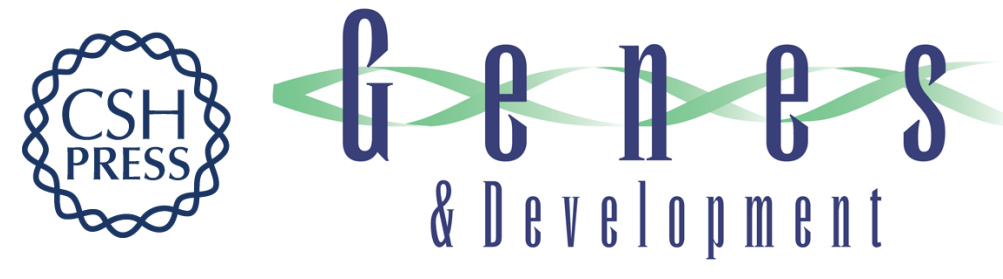

\section{Identification of factors that interact with the E1A-inducible adenovirus E3 promoter.}

H C Hurst and N C Jones

Genes Dev. 1987, 1:

Access the most recent version at doi:10.1101/gad.1.10.1132

References This article cites 47 articles, 18 of which can be accessed free at: http://genesdev.cshlp.org/content/1/10/1132.full.html\#ref-list-1

License

Email Alerting Receive free email alerts when new articles cite this article - sign up in the box at the top Service right corner of the article or click here.

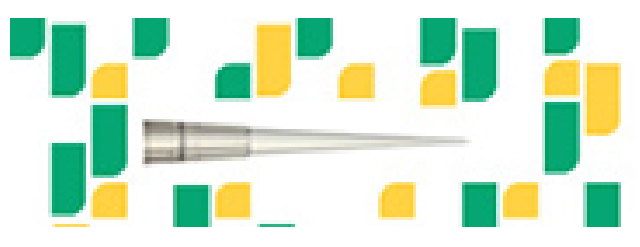

Focused on your science. 